\title{
Preferencje żywieniowe studentów kierunku pielęgniarstwo w zależności od wieku
}

\section{Nutritional preferences of nursing students according to age}

\author{
ANGELIKA NAWROCKA ${ }^{1}$, MAGDALENA ZAWIDZKA ${ }^{1}$, ELŻBIETA \\ NAZAR ${ }^{1}$, KAMILA WITKOWSKA ${ }^{1}$, ALEKSANDRA MICHALAK ${ }^{1}$, \\ EWELINA PACEK ${ }^{1}$, BEATA HAOR ${ }^{2}$ \\ ${ }^{1}$ Studenckie Koło Naukowe Nauk o Zdrowiu, Instytut Nauk o Zdrowiu PWSZ we \\ Włocławku \\ 2 Państwowa Wyższa Szkoła Zawodowa we Włocławku, Instytut Nauk Zdrowiu PWSZ we \\ Włocławku
}

DOI: http://dx.doi.org/10.21784/lwP.2017.010

ISSN: 2451-1846

\section{Streszczenie}

Wstęp. Cukrzyca typu 2 jest chorobą przewlekłą, rozwija się często bezobjawowo, nie wykazując problemów klinicznych, natomiast często po rozpoznaniu towarzyszą już jej powikłania mikronaczyniowe i makronaczyniowe. Przewlekła choroba zmienia obraz świata, przewartościowuje życie większości osób, które zmuszone są do zmiany swoich życiowych celów. W zależności od zaistniałej sytuacji każdy człowiek inaczej reaguje na chorobę. Jedni ludzie akceptują ten stan, inni nie mogą pogodzić się z faktem choroby. Cel. Celem badań było wskazanie zależności między zaakceptowaniem przez pacjentów cukrzycy typu 2, a jakością ich życia. Jednocześnie na 
podstawie przeprowadzonych badań można ocenić przystosowanie się do życia z chorobą.

Materiał i metody. W badaniach wzięło udział 80 osób ze zdiagnozowaną cukrzycą typu 2. Byli to pacjenci hospitalizowani w Oddziale Chorób Wewnętrznych i zarejestrowani w Poradni Diabetologicznej Zespołu Opieki Zdrowotnej w Chełmnie. Jako narzędzie badawcze zastosowano Kwestionariusz Oceny Jakości Życia SF-36 oraz kwestionariusz AIS. Na przeprowadzenie badań uzyskano zgodę powyższej placówki oraz Komisji Bioetycznej.

Wyniki. Średni wartość punktowa jakości życia wyniosła wśród badanych - 78,64 punktu. Wynik ten wskazuje, że badane to grupa o przeciętnym poziomie jakości życia, na granicy poziomu wysokiego. Największy negatywny wpływ na poziom jakości życia badanych miało ogólne poczucie zdrowia. Ze wszystkich obszarów akceptacji choroby, najwyżej ocenili badani poczucie - myślę, że ludzie przebywający ze mną są często zakłopotani z powodu mojej choroby średnia3,74 punktu oraz mój stan zdrowia sprawia, że nie czuję się człowiekiem pełnowartościowym - średnia 3,64 punktu.

Wnioski. 1. Pacjenci wykazujący wyższy stopień akceptacji lepiej funkcjonują w sferze emocjonalnej i fizycznej, a co za tym idzie mogą realizować się $\mathrm{w}$ sferze zawodowej oraz społecznej. 2. Pacjenci wykazujący wyższy stopień akceptacji choroby łatwiej przystosowali się do ograniczeń narzuconych przez chorobę. 3. Pacjenci wykazujący wyższy stopień akceptacji choroby czują się ludźmi pełnowartościowymi.

Słowa kluczowe: żywienie, studenci, pielęgniarstwo

\section{Abstract:}

Introduction. Eating preferences depend on the respondent's age. Healthy diet determines the health condition.

Aim. The aim of the research was to analyze nutritional preferences of students of the nursing faculty and determine the correspondence between students' age and healthy diet.

Material and methods. The research was conducted among Bachelor degree nursing students. The diagnostic survey method was applied, whereas the Health Behaviour Inventory served as a research tool. 
Results. The research has shownthat age affects students' food preferences. Best food preferences were declared by students aged 31 or more, slightly worse behaviour in this respect refers to students aged 19 or younger and to those aged 20-25. Healthy eating habits included: eating vegetables and fruit, wholemeal bread, appropriate nutrition. However, a high level of sugar, salt, animal fat and canned salty food consumption among the youngest group of students(aged 19 and under or 20-25 years) is a matter of concern.

Conclusions. Nursing students have good nutritional preferences. Nutritional preferences depend on age of the students.

Keywords: nutrition, students, nursing

\section{Wstęp}

Istnieje wiele definicji terminu zdrowie. Najbardziej trafnymi wydają się te, które traktują zagadnienie holistycznie, tj. jako sumę prawidłowo funkcjonujących sfer: biologicznej, psychologicznej i społecznej człowieka. Zgodnie $\mathrm{z}$ definicją Światowej Organizacji Zdrowia (1948) zdrowie jest stanem pełnego dobrego samopoczucia fizycznego, psychicznego, społecznego, a nie wyłącznie brakiem choroby lub niedomaganiem [1]. W literaturze specjalistycznej różnych dziedzin zdrowie jest opisywane jako stan, dyspozycja, proces oraz wartość. Zgodnie z typologią wartości Ossowskiego zdrowie może być wartością odczuwaną, uznawaną, odświętną lub codzienną [2]. Bez względu na przyjętą teorię zdrowie jest czynnikiem determinującym jakość ludzkiego życia.

Jednym ze sposobów dbania o zdrowie są tzw. zachowania prozdrowotne. Zgodnie $\mathrm{z}$ definicją Sicińskiego jest to zespół codziennych zachowań, swoistych dla danej zbiorowości lub jednostki, charakterystyczny sposób bycia, odróżniający daną zbiorowość lub jednostkę od innych, lub inaczej, bardziej lub mniej świadomie przyjmowana strategia życia [3]. W koncepcji Lalonde'a z 1974 roku wśród determinantów zdrowia na pierwszym miejscu znalazł się styl życia $\mathrm{z}$ wynikiem pięćdziesięciu procent. $\mathrm{Na}$ dalszych miejscach Lalonde wymienił środowisko i czynniki genetyczne. Na ostatnim miejscu w polach zdrowia pojawiła się organizacja opieki zdrowotnej. 
Również w modelu ekosystemu człowieka, tzw. mandalach zdrowia, styl życia został wymieniony jako istotny czynnik, wpływający na zdrowie człowieka [4].

Prozdrowotny styl życia jest według Cockerhama wzorem świadomych zachowań związanych ze zdrowiem, będących efektem wyborów dokonywanych przez ludzi na podstawie dostępnych, determinowanych ich sytuacją życiową alternatyw [5]. Przykładem zachowania prozdrowotnego jest przestrzeganie zasad zdrowej diety, co jest bardzo ważne $\mathrm{w}$ czasach $\mathrm{z}$ dominacją wysoko przetworzonej żywności. Inne zachowania prozdrowotne to m.in. dbałość o ciało, aktywność fizyczna, sen, wsparcie społeczne, unikanie nadmiaru stresu, radzenie sobie z problemami i stresem, działania prewencyjne, unikanie stosowania używek [6].

Promowanie zachowań prozdrowotnych powinno być nadrzędnym celem polityki zdrowotnej każdego kraju. Choroby cywilizacyjne, których przyczyną jest m.in. nieprawidłowe odżywianie, dotyczą znaczącego odsetka Światowej populacji, a według specjalistów zachorowalność te na jednostki chorobowe będzie wzrastać. Nieprawidłowa dieta jest bowiem przyczyną zwiększonej zachorowalności na choroby układu krążenia oraz nowotworowe, stanowiące najczęstszą przyczynę zgonów w krajach europejskich [7].

Celem badań przedstawionych $\mathrm{w}$ opracowaniu była analiza nawyków żywieniowych wśród studentów kierunku pielęgniarstwa.

\section{Materiał i metody}

Badania przeprowadzono wśród 49 studentów pierwszego roku kierunku pielęgniarstwo, realizujących stacjonarne studia pierwszego stopnia w Państwowej Wyższej Szkole Zawodowej we Włocławku. W badaniu zastosowano metodę sondażu diagnostycznego, metodę szacowania, technikę ankietowania i technikę skali szacunkowej. Narzędziem badawczym był kwestionariusz Inwentarza Zachowań Zdrowotnych, którego treść 
stanowiły pytania dotyczące m.in. spożywania warzyw, owoców i pieczywa pełnoziarnistego, dbania o prawidłowe odżywianie, ograniczenia spożywania tłuszczów zwierzęcych, cukru, soli, silnie solonej żywności, unikania spożywania żywności z konserwantami [8].Kwestionariusz IZZ został zakupiony w Pracowni Testów Psychologicznych Polskiego Towarzystwa a na potrzeby aktualnych badań uzupełniony o metryczkę $\mathrm{z}$ danymi socjodemograficznymi respondentów.

Udział w badaniach było dobrowolny i anonimowy. Po wstępnej weryfikacji kompletności i prawidłowości wypełnienia kwestionariuszy ankiet, nastąpił etap szczegółowej analizy wyników ankiety. Na początku badaną grupę przeanalizowano na podstawie wieku, a następnie wykonano analizę pod względem nawyków żywieniowych, istotnych $\mathrm{z}$ punktu widzenia przeprowadzonego badania. Wyniki zaprezentowano za pomocą wykresów, przedstawiających procentowy udział poszczególnych grup wiekowych w wybranych zagadnieniach. Rycina 1 prezentuje charakterystykę wieku badanych.

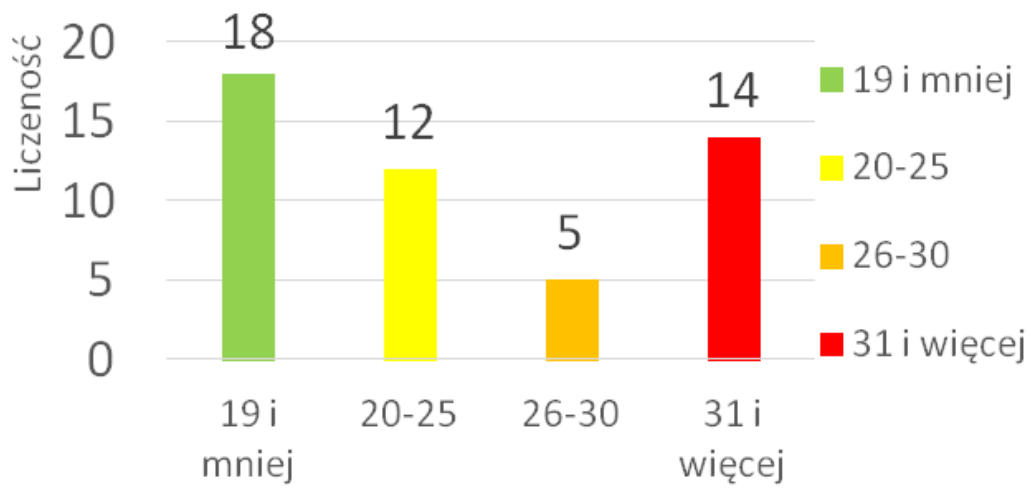

\section{Wiek badanych}

\section{Rycina 1. Charakterystyka badanych ze względu na wiek.}

Źródło: opracowanie własne 
Respondenci zostali podzieleni na cztery przedziały wiekowe: 19 lat i mniej, 20-25 lat, 26-30 lat, 31 lat i więcej. Najliczniejszą grupę stanowiły osoby w wieku 19 lat i mniej $(36,7 \%)$. Kolejne miejsce zajęła grupa w wieku 31 lat i więcej $(28,6 \%)$. Trzecią grupą były osoby w wieku 20-25 lat, a najmniej liczną osoby w wieku 26-30 lat.

\section{Wyniki}

W kwestionariuszu IZZ respondenci oceniali każde zagadnienie według pięciopunktowej skali, gdzie: 1 - prawie nigdy, 2 - rzadko, 3 od czasu do czasu, 4 - często, 5 - prawie zawsze. Rycina 2 prezentuje nawyki żywieniowe studentów.

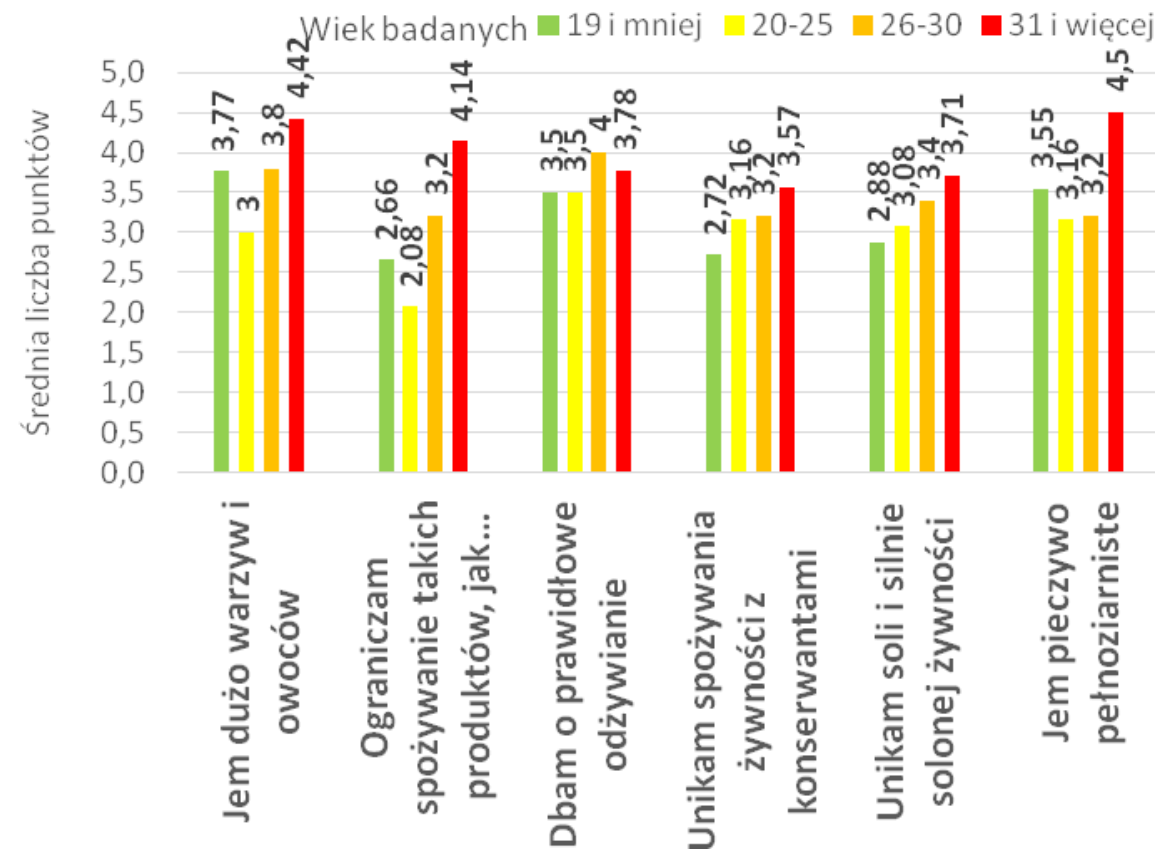

\section{Rycina 2. Nawyki żywieniowe.}

Źródło: opracowanie własne

Powyższa rycina 2 prezentuje końcową liczbę punktów poszczególnych zagadnień $\mathrm{z}$ podziałem na wiek respondentów. 
Największą liczbę punktów zdobyła grupa badanych w wieku 31lat i więcej, co oznacza, że w największym stopniu zwraca uwagę na tak istotne aspekty zdrowej diety jak: spożywanie warzyw, owoców, pieczywa pełnoziarnistego oraz ograniczanie soli, cukru, tłuszczów zwierzęcych i żywności konserwowanej. Dobre nawyki żywieniowe zadeklarowała także grupa badanych w przedziale wiekowym 26-30. Najsłabsze wyniki osiągnęły najmłodsze grupy wiekowe, które w mniejszym stopniu ograniczają spożycie niezdrowych cukru, soli, żywności z konserwantami, tłuszczów zwierzęcych. Na uwagę zasługuje jednak deklarowane $\mathrm{w}$ najmłodszych grupach wysokie spożycie warzyw i owoców oraz pieczywa pełnoziarnistego.

Rycina 3 prezentuje wyniki studentów w zakresie spożywanie warzyw i owoców. Niemal każda grupa zadeklarowała wysoki poziom spożycia tych produktów.

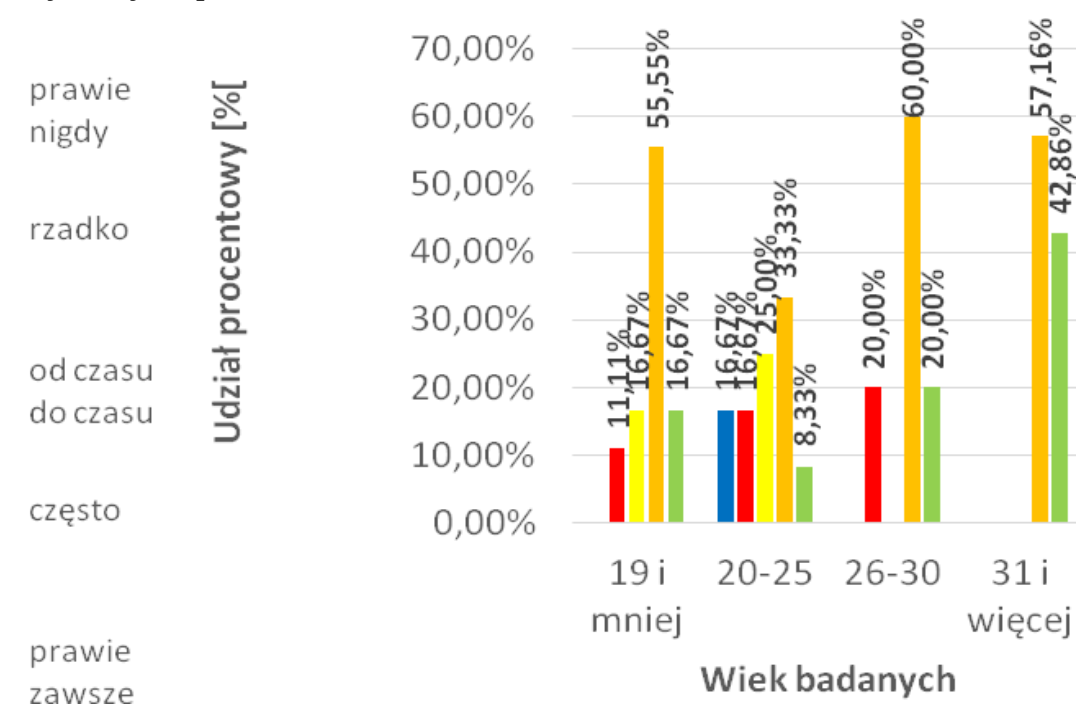

Rycina 3. Spożywanie warzyw i owoców.

Źródło: opracowanie własne

Jak wynika $\mathrm{z}$ ryciny 3 spożycie warzyw i owoców jest zadowalające $w$ każdej z grup. Najczęściej uwzględnianie ich $\mathrm{w}$ diecie 
zadeklarowała grupa osób w wieku 31 lat i więcej, oceniając je jako „często” lub „prawie zawsze” uwzględniane w jadłospisie. Najmniejsza ilość warzyw znajduje się w diecie osób w wieku 20-25 lat, gdzie ponad 60\% badanych „prawie nigdy”, „rzadko” lub tylko „od czasu do czasu" włącza warzywa i owoce do diety. Porównywalne spożycie warzyw występuje w grupach osób w wieku 19 lat i mniej oraz 26-30 lat.

Na rycinie 4 zaprezentowano wyniki dotyczące ograniczenia spożywania następujących produktów: tłuszczów zwierzęcych oraz cukru.

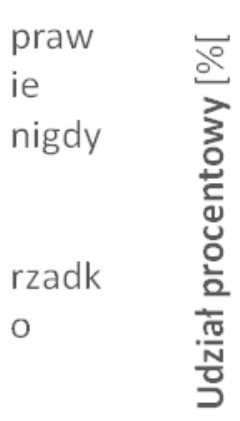

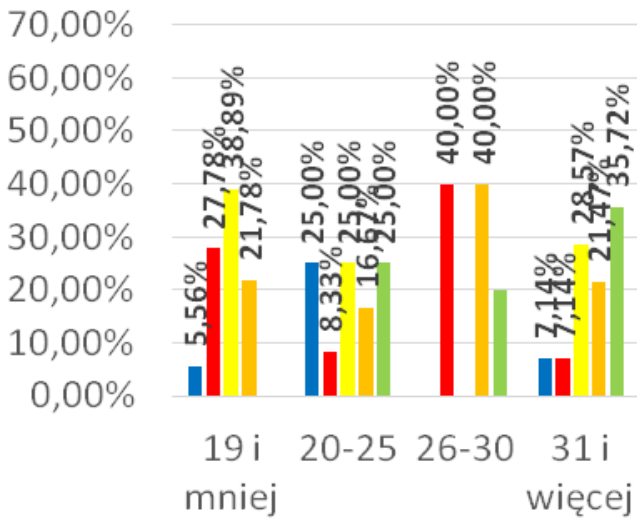

Wiek badanych

\section{Rycina 4. Spożywanie tłuszczów zwierzęcych i cukru.}

Źródło: opracowanie własne

Jak wynika z powyższej ryciny 4 respondenci dwóch grup zadeklarowali niezadowalający poziom ograniczenia podaży tłuszczów zwierzęcych oraz cukru. Około 70\% osób w grupach 19 lat i mniej lat oraz 20-25 lat nie ogranicza lub ogranicza, ale od czasu do czasu spożycie tłuszczów zwierzęcych i cukru. W grupie 26 -30 lat ten sam odsetek respondentów, tj. 40\%, zadeklarował rzadkie i częste ograniczanie spożywania wymienionych produktów. Najlepszy wynik uzyskała badani w wieku 31 i więcej lat, gdzie przeszło połowa 
studentów często lub prawie zawsze eliminuje wymienione składniki pokarmowe z diety.

Na rycinie 5 znajdują się dane dotyczące dbania o prawidłowe odżywianie.

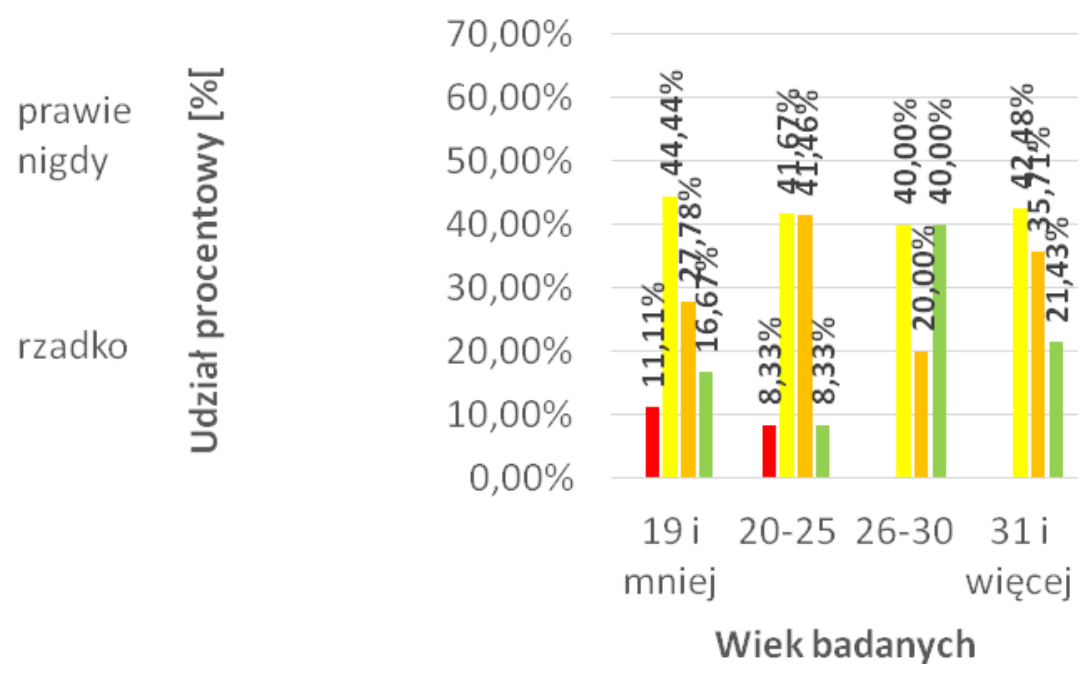

\section{Rycina 5. Dbałość o prawidłowe odżywianie.}

Źródło: opracowanie własne

Z powyższej ryciny 5 wynika, że w każdej z grup około $40-50 \%$ osób deklaruje, że rzadko lub tylko od czasu do czasu dba o prawidłowe odżywianie. Bardzo dobry wynik dotyczył badanych w wieku 26-30 lat, gdzie 60\% respondentów zadeklarowało częste lub prawie zawsze dbanie o prawidłowe odżywianie. Nieco gorszy wynik uzyskali studenci w wieku 31 i więcej (około 57\%).

Na rycinie 6 zaprezentowano stopień spożywania żywności z konserwantami wśród studentów kierunku pielęgniarstwo. 


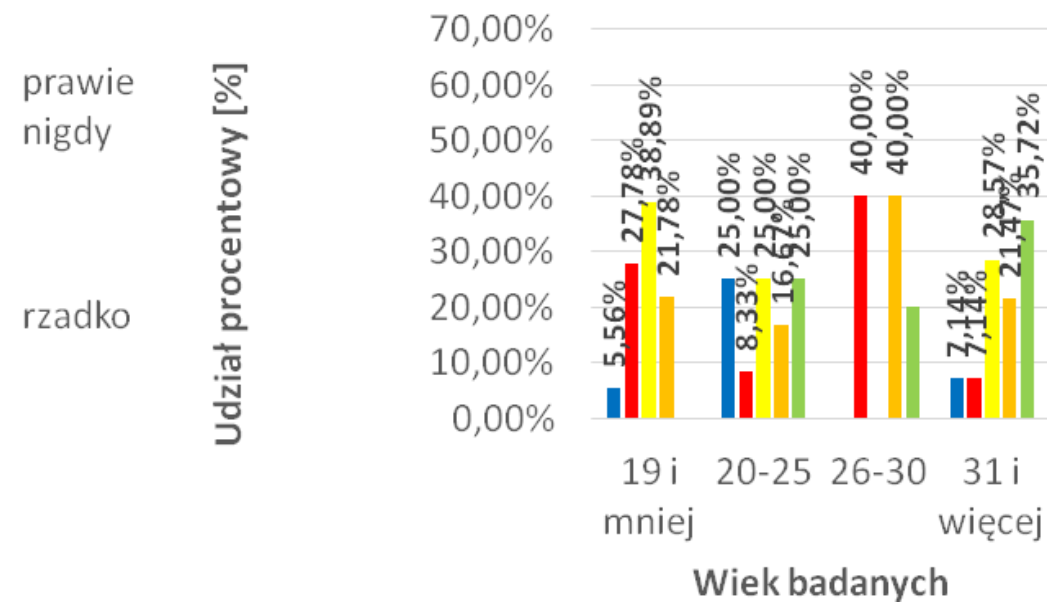

\section{Rycina 6. Spożywanie żywności z konserwantami.}

Źródło: opracowanie własne

Jak wynika z ryciny 6 spożycie żywności z konserwantami jest najwyższe $\mathrm{w}$ grupie studentów w wieku 19 lat i mniej. Ponad $72 \%$ respondentów tej grupy prawie nigdy, rzadko lub tylko od czasu do czasu unika żywności konserwowanej. Niezadowalający wynik prezentuje również grupa $\mathrm{w}$ wieku 20-25 lat, gdzie blisko $60 \%$ ankietowanych również prawie w ogóle nie ogranicza spożycia wymienionych produktów. Zadowalające wyniki uzyskały grupy osoby w wieku 26-30 lat oraz 31 lat i więcej, w których około 60\% badanych zadeklarowało unikanie żywności konserwowanej.

Na rycinie 7 znajdują się wyniki dotyczące spożycia soli. 


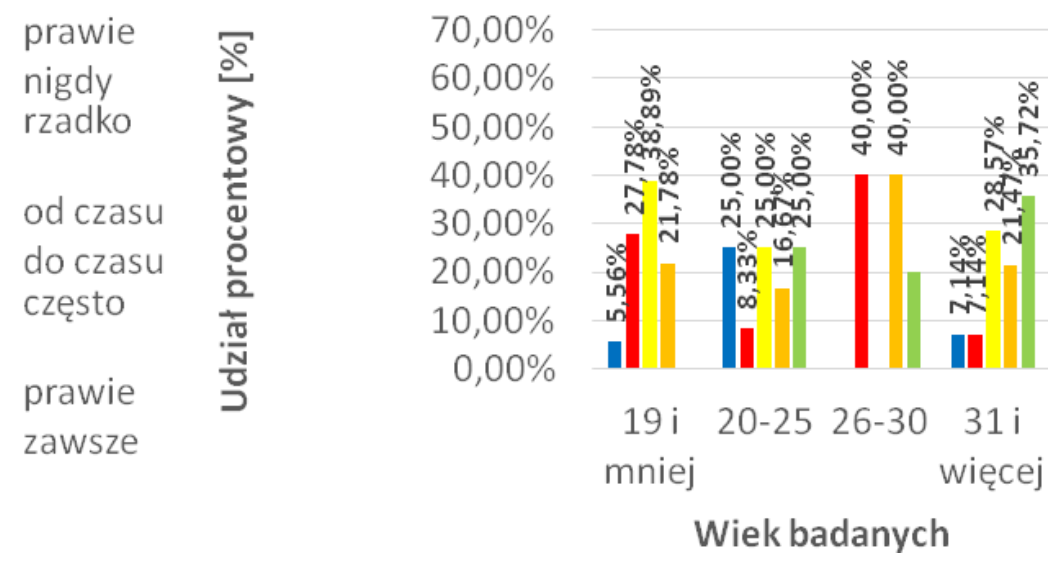

\section{Rycina 7. Spożycie soli i silnie solonej żywności.}

Źródło: opracowanie własne

Jak wynika z ryciny 7 spożycie soli i silnie solonej żywności jest najwyższe w grupie osób w wieku 19 lat i mniej - aż 80\% respondentów zadeklarowało rzadkie ograniczanie popularnej substancji konserwującej. Wysoki odsetek spożycia soli i produktów solonych dotyczył grupy w wieku 20-25 lat (około 60\%) i 26-30 lat (40\%). W grupie wiekowej 31lat i więcej blisko 60\% respondentów zadeklarowało ograniczenie ilości soli w diecie.

Na rycinie 8 podano wyniki dotyczące spożywania pieczywa pełnoziarnistego. 


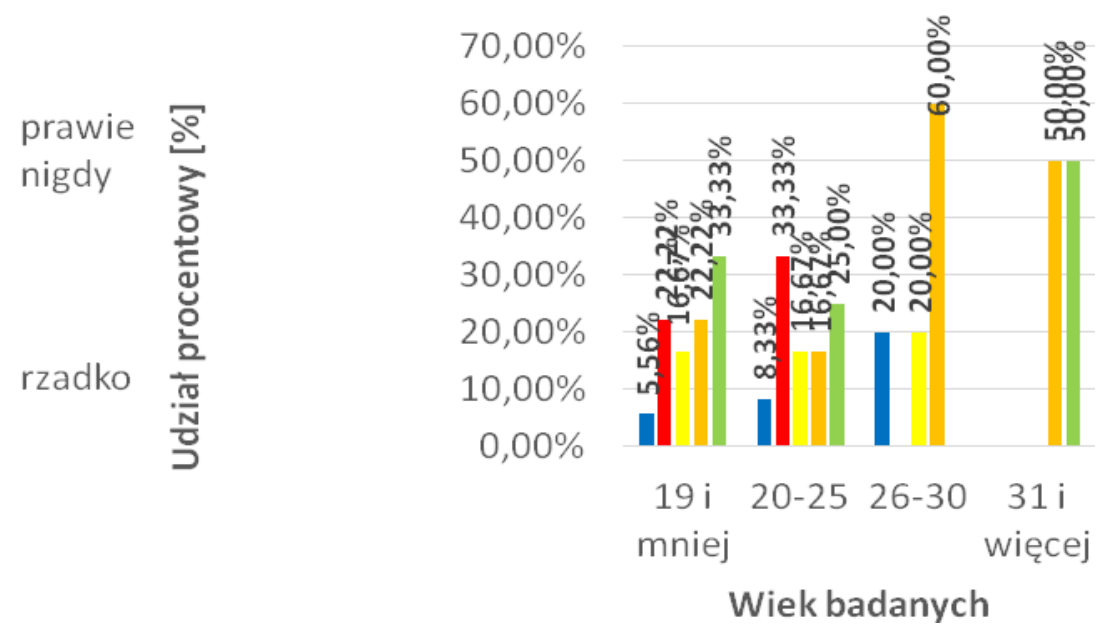

Rycina 8. Spożycie pieczywa pełnoziarnistego.

Źródło: opracowanie własne

Jak wynika z ryciny 8 spożycie pieczywa pełnoziarnistego w najwyższym odsetku dotyczyło najstarszej grupy respondentów, w której w równym stopniu wybierano odpowiedź często i prawie zawsze (po 50\%). Częste spożycie pieczywa pełnoziarnistego zadeklarowała grupa wiekowa 26-30 lat (60\%). Najmniej o tę kwestię dba grupa w wieku 20-25 lat, gdzie blisko 60\% badanych zadeklarowało rzadkie spożywanie pieczywa pełnoziarnistego. Zdecydowanie lepszy wynik odnotowała grupa osób w wieku 19 lat i mniej, w której pond 55\% osób wybrało częste spożywanie pieczywa pełnoziarnistego.

\section{Dyskusja}

Wyniki badań przeprowadzonych wśród studentów kierunku pielęgniarstwo PWSZ we Włocławku wskazują na satysfakcjonującą jakość nawyków żywieniowych. Wyniki ankiety wskazują na związek między sposobem odżywiania a wiekiem respondentów. Najzdrowsze nawyki żywieniowe deklarowała najczęściej grupa osób w wieku 
31 i więcej lat. Niepokojące wyniki odnotowano wśród badanych w wieku 19 lat i mniej oraz 20-25 lat. Jednak na podstawie wyników ankiety można przypuszczać, że wraz z wiekiem należy liczyć na zmianę preferencji żywieniowych studentów, co pozwoli uniknąć w przyszłości niepożądanych konsekwencji zdrowotnych.

Zdrowe odżywianie jest nieodłącznym elementem prozdrowotnego stylu życia, który obecnie jest świadomym wyborem wielu osób. W różnego rodzaju instytucjach oraz mediach temat właściwego sposobu odżywiania jest niemal ciągle poruszany, gdyż zakres wiedzy na ten temat ciągle się poszerza. Można jednak zaobserwować, co jest niestety niepokojące, że moda na zdrowe odżywianie często przybiera skrajne postacie, zwłaszcza wśród młodych, podatnych na wpływy osób, głównie kobiet. Zdrowe odżywianie bywa przez nie utożsamiane wyłącznie ze znacznym ograniczeniem ilości spożywanych pokarmów, co $\quad$ w wielu przypadkach może doprowadzać do ciężkich chorób, np. anoreksji. $\mathrm{Z}$ drugiej strony, mimo odpowiedniej polityki zdrowotnej, wielu kampanii społecznych, obecności programów profilaktycznych w szkołach, w Polsce rośnie odsetek osób z nadwagą i otyłością. Według danych GUS z 2009 roku aż 64\% mężczyzn oraz 49\% kobiet żyjących w Polsce ma nadwagę lub dotyczy ich otyłość[9]. Ten niepokojący trend obserwuje się również wśród uczniów szkół podstawowych i gimnazjów - już około $23 \%$ ma nadwagę lub otyłość [10]. Dlatego ważna jest promocja zdrowych nawyków żywieniowych, zwłaszcza przez osoby pracujące w środowisku medycznym.

Jak pokazują wyniki badań własnych, studenci kierunku pielęgniarstwa preferują następujące nawyki żywieniowe: wysoką podaż warzyw i owoców oraz pieczywa pełnoziarnistego, ograniczenie spożywania produktów zawierających sól, cukier, konserwanty, eliminację tłuszczów zwierzęcych. Preferencje żywieniowe studentów zależą od ich wieku. Zgodnie z wynikami przeprowadzonego badania zasady prawidłowej diety są w większym stopniu przestrzegane przez osoby w wieku 31 lat i więcej. 


\section{Wnioski}

Przeprowadzone badania i analiza wyników wskazują na to, że:

1. Preferencje żywieniowe studentów pielęgniarstwo są poprawne.

2. Należy ograniczyć podaż soli, cukru i konserwantów w młodszych grupach wiekowych.

3. Preferencje żywieniowe wyraźnie zależą od wieku respondentów.

\section{Zalecenia dla praktyki pielęgniarskiej}

Przestrzeganie przez studentów kierunku pielęgniarstwo zasad zdrowego żywienia może wpływać na kształtowanie prawidłowych wzorców wśród odbiorców usług medycznych, tj. na zachęcenie ich do rezygnacji z niezdrowych produktów i składników odżywczych. Propagowanie wśród pacjentów zasad prawidłowego odżywiania wymaga przyjęcia właściwej postawy przez członków zespołu terapeutycznego.

\section{Bibliografia/Bibliography:}

1. Constitution of the World Helath Organization. 22 czerwca 1946. http://apps.who.int./gb/gov/assets/constitution-en.pdf. Data dostępu: 10.06.2017.

2. Ossowski S.: Dzieła: Z zagadnień psychologii społecznej. Tom 3. Polskie Wydawnictwo Naukowe PWN, Warszawa 1967.

3. Siciński A. Style życia $\mathrm{w}$ miastach polskich (u progu kryzysu). Wydawnictwo Polskiej Akademii Nauk, Wrocław 1988.

4. Borzucka-Sitkiewicz K. Promocja zdrowia i edukacja zdrowotna. Przewodnik dla edukatorów zdrowia. Oficyna Wydawnicza Impuls, Kraków 2006. 
5. Ostrowska A. Styl życia a zdrowie. Z zagadnień promocji zdrowia. Wydawnictwo IFiS PAN, Warszawa 1999.

6. Woynarowska B. Edukacja zdrowotna. Podręcznik akademicki. Wydawnictwo Naukowe PWN, Warszawa 2013.

7. Dane statystyczne dotyczące przyczyn zgonu. Źródło: http://ec.europa.eu/eurostat/statisticsexplained/index.php/Causes_of death_statistics/pl. Data dostępu:10.06.2017.

8. Juczyński Z. Narzędzia pomiaru w promocji i psychologii zdrowia. Pracownia Testów Psychologicznych Polskiego Towarzystwa Psychologicznego, Warszawa 2009.

9. Główny Urząd Statystyczny, Departament Badań Społecznych. Stan ludności Polski w 2009r. Warszawa 2011. http://stat.gov.pl/obszary-tematyczne/zdrowie/zdrowie/stanzdrowia-ludnosci-polski-w-2009-r,6,5.html. Data dostępu: 10.06.2017.

10. Badanie przeprowadzone przez Instytut Żywności i Żywienia w ramach projektu: „Zapobieganie nadwadze i otyłości oraz chorobom przewlekłym poprzez edukację społeczeństwa w zakresie żywienia i aktywności fizycznej (KIK/34)" współfinansowanego przez Szwajcarię w ramach szwajcarskiego programu współpracy z nowymi krajami członkowskimi Unii Europejskiej. Dane za 2013r. Kierownik projektu: prof. Mirosław Jarosz. http://www.zdrowie.gov.pl/opis-399kik_34_zachowaj_rownowage.html. Data dostępu: 10.06.2017. 